\title{
Youth Labour Market Frictions in Main MENA Region Countries: Sources and Consequences
}

\author{
Jihène Jebeniani ${ }^{1}$, Jamel Trabelsi ${ }^{2}$ \\ ${ }^{1}$ Institute of Higher Business Studies (IHEC Carthage), University of Carthage, Carthage, Tunisia \\ ${ }^{2}$ BETA, University of Strasbourg, Strasbourg, France \\ Email: jihene.jebeniani@gmail.com, trabelsi@unistra.fr
}

How to cite this paper: Jebeniani, J., \& Trabelsi, J. (2020). Youth Labour Market Frictions in Main MENA Region Countries: Sources and Consequences. Modern Economy, 11, 1696-1718. https://doi.org/10.4236/me.2020.1110117

Received: May 31, 2020

Accepted: October 27, 2020

Published: October 30, 2020

Copyright (c) 2020 by author(s) and Scientific Research Publishing Inc. This work is licensed under the Creative Commons Attribution International License (CC BY 4.0).

http://creativecommons.org/licenses/by/4.0/

\begin{abstract}
We propose to evaluate the impact of education/skill mismatch through an extended version of Duncan and Hoffman equation and matching method by using the SWTS conducted by ILO for the main MENA region countries. Our empirical findings reveal that the youth labor market of these countries did not exhibit the same pattern of frictions. We find that Tunisian youth is more affected by over education phenomenon which implies the analysis of the return to education. More particularly, our findings show that concerning Egypt, Jordan and Tunisia, the marginal benefits that individuals expected to obtain at university level are significant. However, the return to education, especially for Tunisia, is largely attenuated when workers are overeducated. These findings suggest that over education introduces a wage penalty, which is more pronounced for Tunisian.
\end{abstract}

\section{Keywords}

Educational Mismatch, Matching, Over-Education, Return to Education, Wage Penalty

\section{Introduction}

Educational mismatch, and more particularly over-education, remains a specific sensitive issue in developed countries. Several studies have found that in such countries, for example Germany (Daly et al., 2000), the United Kingdom (Sloane et al., 1999; Dolton \& Silles, 2003) and the United States (Rumberger, 1981; Daly et al., 2000; Tsai, 2010), overeducated workers have lower wage compared to those matched ones with the same educational attainment (Pecoraro, 2016). Hartog (2000) and van de Werfhorst and Mijs (2010) argued that the return of education for the overeducated is about half to two-thirds of the return to that of 
the well matched.

Despite the growing body of the literature on over education, few studies have been conducted in developing countries. The annual report of European Commission (2013), however, reveals that Mediterranean countries are severely affected by educational mismatch, a fact largely due to the segmentation of the labor market, a large informal economy and an unequal unemployment distribution across groups and regions. In this context, the labor market in main Mena countries provides a good study case. There is a variety of reasons motivating this research; with the most prominent being, the explosive growth in the number of university graduates, especially between 1999 and 2010. This explosive growth of the educated labor supply significantly contributed to labor market frictions by leading a surplus of skilled workers. Many of whom struggle to find a job to match their expectations, leading to the acceptance of jobs for which they are overeducated and which offer a lower rate of pay. As previously stated, numerous empirical findings confirm the wage penalty on over-education in developed countries. In this paper, we aim to assess the extent of this phenomenon in Egypt, Jordan and Tunisia by using the School-to-Work Transition Survey (SWTS) data. These data are taken from the 2014, 2015 and 2013 International Labor Office (ILO) survey in Egypt, Jordan and Tunisia respectively; they will be described with details in Section 4.

The benchmark model for the empirical estimation of the returns to education is the wage equation, derived by Mincer (1974) who, using US data from 1960, found that the returns to schooling were around 10 per cent. However, in recent literature, there is no consensus or evidence on the relationship between wage and education. Many studies based on quantile regression methods suggest that the returns are higher for those in the top decile of the income distribution compared to those in the bottom decile. One explanation for this phenomenon is a complementarity between ability and education. To quantify the education/skill mismatches, we asked the respondents to indicate if they feel that their education/training qualifications are relevant in performing their present job? With response categories: Yes, appropriate; No, my qualifications higher than required; No, my qualifications less than required (I need more training). According to the question, one can observe that the distinction between education and skills is given by the training or social capital. However, the culture of the social capital and training are still informative stages and the quality of education constitutes the main factor of skills.

Our study is the first to focus on the role of skill mismatches on returns to education in main MENA region countries. In this paper, we propose to develop, through an extended version of Duncan and Huffman specification and matching method, the empirical literature on return at education and to highlight the role of the overeducation to generate wages penalty, especially for university graduates.

Our empirical findings reveal that the frictions in labor market are signifi- 
cantly different from one country to another. More particularly, we showed that the wages penalty is more important in Tunisian than in the rest of the countries (Jordan and Egypt) and higher education was more affected by this friction. In sum, we can argue that the massification of higher education results in producing unemployed and overeducated workers, especially among university graduate. This friction in the labor market, observed particularly in Tunisia is creating a situation of too great wage disparity among young workers.

The remainder of the paper is organized as follows. Section 2 presents the principal stylized facts and empirical results in the economics literature on skill mismatches and return to education. Section 3 describes the dataset and the adopted methodology, and reports the empirical results. Section 4 concludes and outlines the policy implications of main finding.

\section{Literature Review}

\subsection{Basic Literature Review}

The literature on the returns to education defines the effect on wage as the main aspects of returns to education measurement. Therefore, many studies focused on the estimation of the impact of education on wage using a wide range of empirical approaches. In recent empirical literature, the Mincer (1974) specification has been extended to deal with the endogeneity bias induced by schooling decision, which the original Mincer (1974) equation does not take into account. Angrist and Krueger (1991) and Card (1999) show, for example, that instrumental variable estimates of returns to education are higher than the Mincerian one. Mincer (1974)'s second model enriched the first version by taking into account the main economic foundations developed by Becker (1964) and Becker and Chiswick (1966). Indeed, this extended version of the Mincer (1974) model includes the concept of the life-cycle dynamics of wage and makes an explicit distinction between observed wage, potential wage and human capital. Mincer (1974)'s models exhibit several important implications and could allow us to understand how individual wage patterns vary with population averages at each age in the life-cycle. Indeed, Mincer (1974) shows, under conditions that: "1) log-wage experience profiles are parallel across schooling level, 2) log-wage age profiles diverge with age a cross schooling levels and 3) the variance of wage over the life-cycle has a $U$-shaped pattern". The empirical results, for data covering the period of 1940-1950, provide support for implications 1) and 2) of Mincer's (1974) model, while data from the period of 1980-1990 reject these two implications. The U-shaped pattern, predicted by Mincer (1974)'s model, is supported by data from 1960 to 1990 . By consequence, several empirical studies relax the assumptions that the log-wage experience profiles are parallel across schooling levels and the log-wage age profiles diverge with age across schooling levels. They also included additional factors such as school tuition, income taxes and experience.

However, the substantial reduction in the returns to schooling observed in the 
US in the 1970s raises the question as to whether an overinvestment in education pays off. Data presented by Smith and Welch (1978) show that between 1967 and 1976 the ratio of the average income of new insiders moved from 24 percentage points to 8. Based on a neoclassical framework, Freeman (1976) argued that this sharp decline is the outcome of the increase in the supply of highly educated workers who compete for a limited number of skilled jobs. As such, they underbid the wage they demand and the firms adjust their production technology to take advantage of the relatively cheaper and abundant input factor of highly educated workers. This process is more generally associated with the economics of over-education, which has been defined as the possession by workers of higher educational skills than their job requires.

The Becker (1964)'s human capital theory states that wage are solely determined by the worker's investment in education. However, Sicherman and Galor (1990) claim that, for a given level of education, individuals may voluntary spend a part of their working career in firms where the direct return to schooling is lower but the probability of promotion is higher. By consequence, and according to Sicherman and Galor (1990), promotion constitutes, through over-education, an indirect consideration for the initial investment in human capital.

Thurow (1975) proposed an alternative approach based on the job-competition theory, which stipulates that wage are determined by requirements of the jobs and not by education (human capital theory). The main idea behind the job-competition theory is that workers are distributed across job opportunities in agreement with their relative position in the labor queue. Following this process, the best jobs will be offered to the most preferable workers and, during recessions, higher educated workers will squeeze lower educated workers out.

The over-education analysis of Duncan and Hoffman (1981) has enriched Freeman (1976)'s macro approach. They argue that for a given job, associated productivity levels and wage are fixed and individuals with overskill produce and earn the same as individuals with less schooling in the same job. They shed light on the mismatches of the current allocation of workers to jobs. The over-education is apparent in the form of mismatches, a fact which is the most debated in the literature. The book of Freeman (1976) spawned a rich literature on the economics of over-education, notably on how the labor market operates. Indeed, the incidence of skill mismatches and wage and the pattern of estimated returns to education have been analysed in terms of different labour market theories.

Duncan and Hoffman (1981) have proposed an extended version of the Mincerian wage equation by imposing that the constraint for individual's wage don't depend on the job characteristics but rather on their education. In fact, their wage equation allows for the separate estimation of returns for years of education required for the job, years of under-education and years of over-education. Verdugo and Verdugo (1989) adopt a modified version of Duncan and Hoffman (1981)'s model by substituting the years of schooling required by the job with the level of education attained by the individual, taking into account the wage 
penalty contracted by an individual for each year of over-education compared with another individual in the same position.

\subsection{Recent Related Literature Review}

Vahey (2000) (Table 1) used data from the National Survey of Class Structure (NSCS) and Labour Process in Canada to estimate the returns to over and under-education. He found that there are positive returns to over-education for males in jobs that require a university bachelor's degree; but for other levels of required education, the returns are insignificant. He also found evidence of lower pay for undereducated males in jobs with low education requirements. For females, the returns to over and under-education are insignificant for all levels of required education.

Budría and Moro-Egido (2008) explored the connection between education and wage inequality in Spain for the period 1994-2001. Using quantile regression, Authors found that higher education is associated with higher wage dispersion. They differentiated between three different types of educational mismatch: "overqualification", "incorrect qualification", and "strong mismatch". And they found that while over-qualification and incorrect qualification are not associated with lower wages, strong mismatch carries a pay penalty that ranges from $13 \%$ to $27 \%$. Thus, by driving a wedge between matched and mismatched workers, the incidence of strong mismatch contributes to enlarge wage differences within education groups.

Quintano et al. (2008) studied the returns of over-education on earnings and on the job-search using a longitudinal survey of a random sample of economics graduates from the University of Naples "Parthenope". Over-education was measured using two different indicators of educational mismatch, one based on an objective parameter and the other on the same parameter combined with a subjective one. A probit regression with selection was used to analyse the influence of a set of control variables (such as family, background, employment geography and characteristics of job, work history, gender and channels used to enter the labour market) on over-education. The same variables were used to study the returns of over-education on earnings and on the jobsearch. The probability of being over-educated was significantly affected by gender, attainments in Higher Education, channels used to enter the labour market, job location and job sector applied for. Females, lower Higher Education achievers and graduates working in trade/sales or information systems sectors were more likely to be over-educated than other subjects, whereas use of further education to enter the labour market decreased the probability of being over-educated. Over-educated workers were found to have a high probability of low earnings.

Cainarca and Sgobbi (2012) studied the incidence of educational mismatch in Italy and the return to investment in education, controlling for employees' ability using original data including over 3600 face-to-face interviews. Findings showed that under-educated employees outnumber over-educated ones and 
Table 1. Summary of reviewed studies.

\begin{tabular}{|c|c|c|c|c|}
\hline Author(s) & Country & Period-Sample & Methodology & Result \\
\hline Vahey (2000) & Canada & $\begin{array}{l}\text { Cross-sectional survey } \\
\text { ( } 3000 \text { respondents } \\
\text { conducted face to face) } \\
\text { in } 1982\end{array}$ & OLS & $\begin{array}{l}\text { (+) R to OvEdu for } M \text { in jobs } \\
\text { with HighEdu; Lower pay for } \\
\text { HighEdu for M in jobs with } \\
\text { low education. } \\
\text { For F, R to OvEdu and UnEdu } \\
\text { are insignificant for all levels } \\
\text { of required education. }\end{array}$ \\
\hline $\begin{array}{l}\text { Budría and } \\
\text { Moro-Egido (2008) }\end{array}$ & Spain & 1994-2001 & OLS & $\begin{array}{l}\text { Strong mismatch carries a pay } \\
\text { penalty that ranges from } 13 \% \\
\text { to } 27 \% \text {. }\end{array}$ \\
\hline Quintano et al. (2008) & $\begin{array}{l}\text { The University of } \\
\text { Naples } \\
\text { "Parthenope" }\end{array}$ & $\begin{array}{l}\text { Random sampling by } \\
\text { graduation year (1999, } \\
2000,2001 \text {, and 2002). }\end{array}$ & $\begin{array}{l}\text { Probit regression } \\
\text { analyses with selection }\end{array}$ & $\begin{array}{l}\text { Prob (OvEd) significantly } \\
\text { affected by M, HighEdu, } \\
\text { channels used to enter the } \\
\text { labour market, job location } \\
\text { and job sector applied for. F, } \\
\text { lower HighEdu achievers } \\
\text { and graduates working in } \\
\text { trade/sales or information } \\
\text { systems sectors were more } \\
\text { likely to be OvEdu than other } \\
\text { subjects, whereas use of fur- } \\
\text { ther education to enter the } \\
\text { labour market decreased the } \\
\text { probability of being } \\
\text { over-educated. OvEdu } \\
\text { workers were found to } \\
\text { have a high probability of } \\
\text { low earnings. OvEdu and } \\
\text { low earnings induced } \\
\text { workers to change jobs. }\end{array}$ \\
\hline $\begin{array}{l}\text { Cainarca and Sgobbi } \\
\text { (2012) }\end{array}$ & Italy & $\begin{array}{l}2004-2006 \\
\text { Original data including } \\
\text { over } 3600 \text { face-to-face } \\
\text { interviews }\end{array}$ & OLS & $\begin{array}{l}\text { UnEdu employees outnumber } \\
\text { OvEdu ones and R to required } \\
\text { education and OvEdu are } \\
\text { lower than in other } \\
\text { industrialised countries. } \\
\text { Individual heterogeneous } \\
\text { ability, as captured by } \\
\text { individual skills, is a } \\
\text { significant determinant of } \\
\text { wage, although the inclusion } \\
\text { of direct measures of required } \\
\text { and provided skills do not } \\
\text { substantially affect the } \\
\text { estimated coefficients of the } \\
\mathrm{R} \text { to investment in education. }\end{array}$ \\
\hline Murillo et al. (2012) & Spain & $\begin{array}{l}\text { 1995-2006 } \\
\text { Spanish Wage Structure } \\
\text { Survey (WSS) }\end{array}$ & ORU estimation & $\begin{array}{l}\mathrm{R} \text { to education have declined; } \\
\text { the } \mathrm{R} \text { associated with the job's } \\
\text { required education is greater } \\
\text { than that corresponding to the } \\
\text { worker's actual schooling, and } \\
\text { that the } \mathrm{R} \text { on an additional } \\
\text { year of attained education is } \\
\text { positive but less than that of } \\
\text { an additional year of required } \\
\text { education. }\end{array}$ \\
\hline
\end{tabular}




\section{Continued}

Bender and Roche

(2013)

USA

García-Pozo et al.

(2014)

Tarvid (2015)

David and Nordman (2017)

Flisi et al. (2017) dataset from the US National Science Foundation (NSF 2013)

Probit regression

Nonparametric kernel methods

ISCED 5 in 1999/2000. The survey was carried out in 2005 among higher graduates

The 2006 Spanish Wage Structure Survey

Mincerian wage specification

European Social Survey Round 5 data

Mixed effect logit

R migrant's job level upon $\mathrm{R}$ and compute the mean and median of approximately 1000 non-migrants and 1000 returnees in each country

PIAAC survey (2013)

Larger earnings penalties for mismatch among the self-employed and no diminution in job satisfaction.

A negative effect of the education-job mismatch on wages in most of the countries.

The R on human capital and the real hourly wage may be quantitatively influenced by educational mismatch.

1) industries form two clusters: low OvEdu-low share of below-tertiary occupations, and high OvEdu-high share of below-tertiary occupations; 2) industries form a continuous cloud along a positively-sloped line; and 3) industries appear along a horizontal line, suggesting no relationship between the two variables.

Tunisian $\mathrm{R}$ migrants are more prone to be OvEdu than Egyptian R.

\footnotetext{
1) a small percentage of mismatched individuals are mismatched with respect to both education and skill, whereas the majority are mismatched with respect to either education or skill only; 2) negative correlation between the incidence of education and skill mismatch.
}

Conceptualisation and measurement of occupational mismatch countries
Survey of the European Training Foundation (ETF) between 2006 and 2007 in Egypt an
Tunisia 


\begin{tabular}{|c|c|c|c|c|}
\hline $\begin{array}{l}\text { Mateos Romero et al. } \\
\text { (2017) }\end{array}$ & $\begin{array}{l}10 \text { European } \\
\text { countries }\end{array}$ & PIAAC database (2013) & $\begin{array}{l}\text { Mincerian classical } \\
\text { equations }\end{array}$ & $\begin{array}{l}\text { 1) Both years of education and } \\
\text { skills contribute to determine } \\
\text { wages, with higher R to years } \\
\text { of education as the level of } \\
\text { skills increases; R to years of } \\
\text { required education and } \\
\text { educational mismatch vary } \\
\text { depending on the skills } \\
\text { acquired by workers, with a } \\
\text { higher premium to years of } \\
\text { OvEdu among workers with } \\
\text { higher levels of skills. }\end{array}$ \\
\hline $\begin{array}{l}\text { Kalfa and Piracha } \\
\text { (2017) }\end{array}$ & Spain & $\begin{array}{l}\text { National Immigrant Survey } \\
\text { of Spain (NIS 2007) } \\
\text { conducted between } \\
\text { November } 2006 \text { and } \\
\text { February } 2007 \text { of } 15,465 \\
\text { individuals, one per } \\
\text { household. }\end{array}$ & Probit with selection & $\begin{array}{l}\text { 1) Probability of OvEdu has a } \\
\text { higher effect on the probability } \\
\text { of being over-educated in the } \\
\text { first job; 2) those who were } \\
\text { OvEdu in their first job are } \\
\text { more likely to continue being } \\
\text { over-educated in their current } \\
\text { job; and 3) OvEdu } \\
\text { immigrants earn significantly } \\
\text { lower wages compared to } \\
\text { their non-overeducated } \\
\text { counterparts. }\end{array}$ \\
\hline $\begin{array}{l}\text { Sharma and Sharma } \\
\text { (2017) }\end{array}$ & India & $\begin{array}{l}2011-2012 \text {. } \\
\text { Survey across } 7469 \text { villages } \\
\text { and } 5268 \text { urban blocks, } \\
\text { covering 101,724 households } \\
\text { and } 456,999 \text { individuals }\end{array}$ & $\begin{array}{l}\text { Multiple Mincerian } \\
\text { equations and the novel } \\
\text { identification strategy of } \\
\text { Lewbel (2012) }\end{array}$ & $\begin{array}{l}\mathrm{R} \text { to OvEdu (+) and } \\
\text { significant; } \mathrm{R} \text { to UnEdu (-) } \\
\text { and significant. OvEdu earn } \\
\text { less than the workers who have } \\
\text { the same educational level, but } \\
\text { who are engaged in } \\
\text { occupations for which they } \\
\text { are adequately educated. }\end{array}$ \\
\hline
\end{tabular}

Return: R; Over-education: OvEdu; Higher Education: HighEdu; Under-education: UnEdu; Male: M; Female: F.

returns to required education and over-education are lower than in other industrialised countries. Individual heterogeneous ability, as captured by individual skills, is a significant determinant of wage, although the inclusion of direct measures of required and provided skills do not substantially affect the estimated coefficients of the return to investment in education.

Murillo et al. (2012) examined the effects of educational mismatch on wages in the Spanish labour market since the mid-nineties. First they studied the evolution of returns to education and then we estimate returns to education in terms of the match between the worker's schooling and the job requirements. The results indicate that returns to education have declined since the mid-nineties. They also found that the return associated with the job's required education is greater than that Corresponding to the worker's actual schooling, and that the return on an additional year of attained education is positive but less than that of an additional year of required education.

Bender and Roche (2013) examined the far less studied influence of mismatch 
on the self-employed. Using a sample of workers in science and engineering fields, authors showed larger earnings penalties for mismatch among the self-employed but no diminution in job satisfaction. Moreover, the reasons for mismatch among the self-employed differ dramatically by gender.

Zamfir et al. (2013) explored the impacts of education-job mismatches on the working benefits of higher education graduates. In order to estimate the "wage penalty", authors analysed REFLEX data set, which includes information on early career outcomes of school leavers graduating ISCED 5 in 1999/2000. The survey was carried out in 2005 among higher graduates from 14 countries. Their cross-country analysis compared the wage distribution of matched graduates with that of the mismatched graduates using nonparametric kernel methods to handle a mix of continuous, unordered, and ordered factor data types. The obtained results show a negative effect of the education-job mismatch on wages in most of the countries.

García-Pozo et al. (2014) analysed the returns on human capital and the importance of educational mismatch in determining wages in the Spanish hospitality and the travel agency sectors. In addition, they assess the impact of several job characteristics (business size, full-time contracts and permanent contracts) and personal characteristics (gender and worker nationality) on wages. Using an expanded Mincerian wage equation and data from the 2006 Spanish Wage Structure Survey, authors estimated separate regressions for each educational group analysed: overeducated, undereducated and adequately educated workers. The findings showed that the return on human capital and the real hourly wage may be quantitatively influenced by educational mismatch.

Tarvid (2015) performed the interaction between industry and the risk of over-education using European Social Survey Round 5 data on 27 countries. Author found that when macro-level variables are included in the over-education model, finance and public administration join these industries in being significantly more open to over-education than manufacturing. Construction is the only industry with significantly lower over-education risk than manufacturing. The exposure to over-education in different industries reflects clear consequences of traditional association of men and women with different industries. Men are more overeducated in administrative services, accommodation and public administration, while women in finance, professional and scientific activities and administrative activities. He showed that countries fall into one of three groups by the pattern of relationship between over-education and the share of occupations from ISCO major groups 4 - 9: 1) industries form two clusters: low over-education-low share of below-tertiary occupations and high over-education-high share of below-tertiary occupations, 2) industries form a continuous cloud along a positively-sloped line, and 3) industries appear along a horizontal line, suggesting no relationship between the two variables.

David and Nordman (2017) explored the subject of education mismatch in the context of return migration in Egypt and Tunisia. Using data on both return and 
non-migrants in Egypt and Tunisia, they analyzed the skills that migrants acquire before and during migration and the way these skills are used upon return. Their findings showed evidence of education mismatch, especially in Tunisia. Authors also estimated the determinants of education mismatch on the Egyptian and Tunisian labour markets and they found a significant positive effect of return migration on the probability of being overeducated.

Flisi et al. (2017) explored the PIAAC survey 2013 to measure occupational mismatch at the individual level based on both education (over-education) and skill-based (over-skilling) variables by using both objective and subjective measures. Authors used data for 17 European countries and compute up to 20 different indicators of occupational mismatch. They found that the conceptualization and measurement of occupational mismatch are indeed important and that education and skill mismatch do not measure the same phenomenon. Findings showed that only a small percentage of mismatched individuals are mismatched with respect to both education and skill, whereas the majority are mismatched with respect to either education or skill only. At the country level, authors also found a negative correlation between the incidence of education and skill mismatch, which has important implications for policies aiming to address this labour market inefficiency.

Kalfa and Piracha (2017) analysed immigrants' educational mismatch and its impact on wages in Spain. The incidence of immigrants' education-occupation mismatch in the Spanish labour market can largely be explained by the mismatch in the last job held in the home country. Authors found that the probability of having been over-educated in the home country has a higher effect on the probability of being over-educated in the first job. In adding, findings showed that those who were over-educated in their first job are more likely to continue being over-educated in their current job. Finally, over-educated immigrants earn significantly lower wages compared to their non-overeducated counterparts.

Mateos Romero et al. (2017) analyzed the returns to education and educational mismatch in ten European countries. Using PIAAC database, their findings indicated that both years of education and skills contribute to determine wages, with higher returns to years of education as the level of skills increases. In addition, findings also found that returns to years of required education and educational mismatch vary depending on the skills acquired by workers, with a higher premium to years of over-education among workers with higher levels of skills. These results tend hence to support the hypothesis of skills heterogeneity and highlight the need of taking account of individuals' skills when analyzing the returns to education and educational mismatch.

Sharma and Sharma (2017) examined the impact of educational mismatch on the earnings for the Indian labor market. It also attempts to measure the wage effects of educational mismatch, and other individual and work-related characteristics using multiple Mincerian equations. Empirical results showed that the returns to over-education are positive and significant, while the returns to un- 
der-education are negative and significant. However, over-educated would earn less than the workers who have the same educational level, but who are engaged in occupations for which they are adequately educated.

\section{Regional Overview on Skill Mismatches (Egypt, Jordan and Tunisia)}

The most striking common feature of labour markets in Egypt, Jordan and Tunisia is the highest rate of unemployment; it has oscillated between $12 \%, 18 \%$ over the past decade to reach the high level of 13.2 in 2013, 16.2 in 2002 and 18\% in 2011 respectively in Egypt, Jordan and Tunisia. Indeed, unemployment in these countries among other SEMCs can be considered structural and not cyclical, to the extent that it affects a very specific group of people-young, educated individuals searching for opportunities the access to the labor market-with substantial gender gaps. There is a positive relationship between high unemployment rates and the high number of educated new entrants to the labor market, resulting from the combination of expanding working age populations and enrolment in higher education.

The data available from censuses show that also rates of participation in the labor force are substantially lower than the world average, hinting at the fact that unemployment is largely a matter of youngsters facing difficulties in entering the labour market, not of adults formerly employed having lost their jobs. In fact, as indicated by Figure 1, the youth unemployment rate was at least twice that of the total unemployment rate. Figure 1 shows that the share of the population aged 15 or more that is economically active is estimated at $49 \%$ in Egypt, $48 \%$ in Tunisia and $42 \%$ in Jordan.

In fact, youth unemployment rates in the three countries are two or three times higher than adult unemployment rates, reaching 34\% in 2016 there is little doubt that conjectural external and internal shocks related to the 2008 global financial and economic crisis and the 2011 political upheavals across the SEMCs contributed to the increasing trends in youth unemployment discussed above.

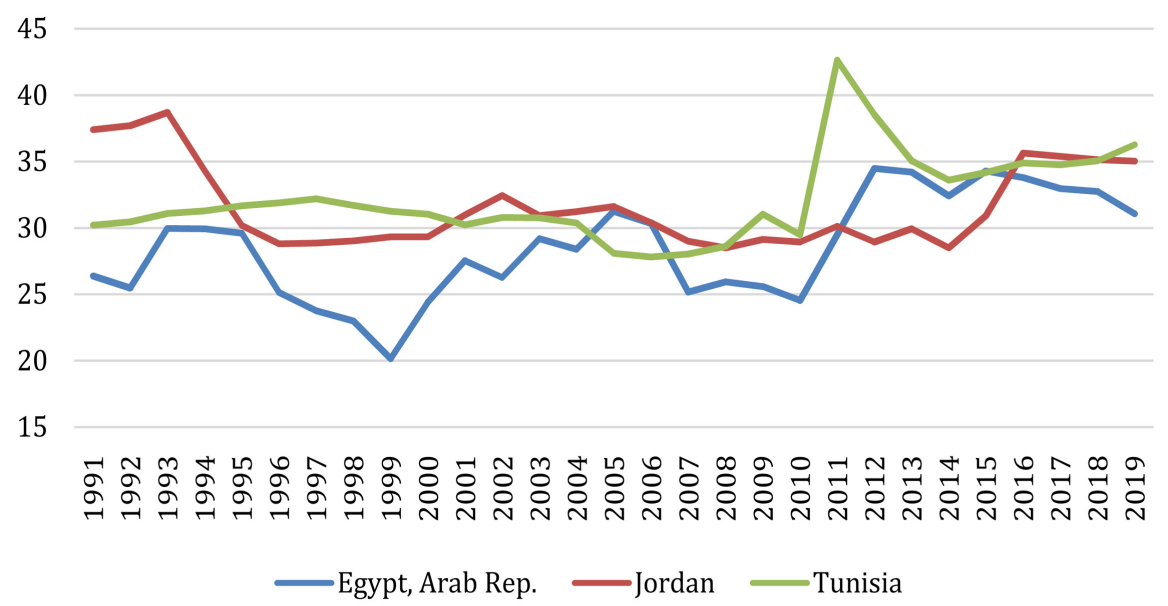

Figure 1. Youth unemployment rate. Source: World bank. 
However, the fact that education does not seem to be a guarantee against unemployment is a rather unique feature of labour markets in the SEMCs as compared to benchmarking regions, pointing at structural problems, among which skills mismatches stand out. The latter refer to the discrepancies between the skills provided by education systems on the demand side and those requested by labour markets on the supply side, which complicate the transition of young graduates from education to employment. Hence, skills mismatches encompass problems on both the demand side, such as the inadequacy of university curricula and educational choices with the needs of the economy, and the supply side, such as the weight of the public sector which provides up to $38 \%$ of total jobs in Jordan and 27\% in Egypt for example, with important consequences on educational choices.

To explain the labour market frictions in the all three countries, it is important to analyze their educational system and identify the desired future sector of employment of youth students. Figure 1 shows that more than half of Jordan youth have finished their education completed at the primary level while in Egypt nearly one in three youth finished their schooling below secondary level (30.3 per cent). The secondary vocational training is of major interested to the Egyptian youth; more than 37 per cent of the respondents completed vocational training at the secondary education level. The low shares at this level of education in Tunisia and more particularly in Jordan should have direct effect on the labour demand in technical fields.

In terms of higher education (Table 2), the percentage of university graduates is lower in Egypt (16.7 per cent) and Tunisia (17.2 per cent) than in Jordan (28.9 per cent) which is in line with literature (Salehi-Isfahani, Tunali, \& Assaad, 2009) whereby the education is restricted to those youth from well-off families ${ }^{1}$ In fact, following the human capital theory there is a high correlation between educational attainment and household income situation.

The statistics reported in Table 3 below confirm this economic hypothesis since 52.3 per cent and 3.7 per cent of youth Egyptians with "well off" and "poor" household statutes, respectively have university degree. The equivalent percentage are 41.5 per cent (37.0 per cent) versus 7.1 (4.7 per cent) per cent for Tunisia (for Jordan). These statistics show that the share of Egyptians and Jordan university graduates with "poor" household statutes seems to be lower than those of their Tunisian counterparts. Much of the deterioration in Tunisian return at education appears directly attributable to the dramatic increase of university enrolments, which grew by $50 \%$ between 2002 and 2010and to the quality of education. In fact, following the literature on the labour market frictions, the sharp decline in wage is the outcome of the increase in the supply of highly educated workers who compete for a limited number of skilled jobs. This process is more generally associated with the economics of overeducation, which has been defined, as the possession by workers of highly educational skills than their job require.

${ }^{1}$ In the samples, Egypt and Tunisia include the larger proportion of rural residents. 
Table 2. Household income situation by highest-level education.

\begin{tabular}{|c|c|c|c|c|c|c|}
\hline Country & Income status & $\begin{array}{c}\text { Less than } \\
\text { Primary }\end{array}$ & Primary & $\begin{array}{l}\text { Secondary } \\
\text { vocational }\end{array}$ & $\begin{array}{c}\text { Secondary } \\
\text { general }\end{array}$ & Tertiary \\
\hline \multirow[t]{5}{*}{ Egypt } & well off & 6.8 & 7.7 & 30.6 & & 52.3 \\
\hline & fairely well off & 10.6 & 14.7 & 31.8 & 3 & 36.9 \\
\hline & $\begin{array}{c}\text { around the } \\
\text { national average }\end{array}$ & 14.1 & 21.6 & 41.4 & 2.1 & 16.3 \\
\hline & fairly poor & 35.9 & 27.4 & 30.1 & 1 & 4 \\
\hline & poor & 34.2 & 36.1 & 23 & 0.9 & 3.7 \\
\hline \multirow[t]{5}{*}{ Jordan } & well off & 3 & 42.7 & 1 & 7.6 & 38.4 \\
\hline & fairely well off & 0.7 & 42.8 & 2.9 & 9.5 & 36.1 \\
\hline & $\begin{array}{c}\text { around the } \\
\text { national average }\end{array}$ & 2.4 & 52.5 & 2 & 10.2 & 27.4 \\
\hline & fairly poor & 2.7 & 69.1 & 5.8 & 9.8 & 10.4 \\
\hline & poor & 23.1 & 55.8 & 3.1 & 10.3 & 4.7 \\
\hline \multirow[t]{5}{*}{ Tunisia } & well off & 2.1 & 19.4 & & 37.1 & 41.5 \\
\hline & fairely well off & 1.9 & 13.2 & 12.3 & 30.1 & 42.5 \\
\hline & $\begin{array}{c}\text { around the } \\
\text { national average }\end{array}$ & 2.2 & 43 & 13.1 & 24.2 & 17.5 \\
\hline & fairly poor & 4.9 & 60.3 & 10.1 & 16.3 & 8.5 \\
\hline & poor & 12.9 & 54.4 & 9.1 & 16.6 & 7.1 \\
\hline
\end{tabular}

As indicated by the Table 3, more than $16 \%$ of Tunisian youth are in overeducation situation; this phenomenon affects more particularly university graduates. Unlike Tunisia, Egypt and Jordan youth are rather affected by undereducation phenomenon with a high level of 42.1 per cent and 55.1 per cent respectively.

In addition to the labour market friction, it is important to stress that the current students showed a tendency to prefer future employment in the government sector. Figure 2 shows that 72 per cent of Jordanian students express their preference to this activity sector while only 13.2 per cent and 9 per cent aspire to attain self-employment and private sector respectively. The equivalent percentage is 65.7 per cent and 57.9 per cent for Tunisia and Egypt respectively. As asserted by Assaad (1997), the declining availability of public sector job in the major MENA countries limits the capacities of the labour market absorption, generating a further increase in unemployment and skill mismatches.

\section{Empirical Analysis}

1) Data and statistical analysis

The data used in this study comes from the school to work transition surveys (SWTS) carried out by ILO in Egypt, Jordan and Tunisia in 2014, 2015 and 2013 
Table 3. Employed youth by overeducation, undereducation or matching qualifications (\%).

\begin{tabular}{ccccc}
\hline Colonne1 & Colonne2 & Colonne3 & Colonne4 & Colonne5 \\
\hline Country & Sex & Overeducated & Undereducated & Matching \\
\hline Egypt & Total & 12.0 & 42.1 & 46.0 \\
& Male & 12.1 & 42.2 & 45.7 \\
Jordan & Female & 11.2 & 41.5 & 47.3 \\
& Total & 5.4 & 48.7 & 45.9 \\
& Male & 4.7 & 55.1 & 40.2 \\
& Female & 8.4 & 21.6 & 70.0 \\
& Total & 16.1 & 33.3 & 50.5 \\
& Male & 17.0 & 30.7 & 52.3 \\
& Female & 14.0 & 39.6 & 46.4 \\
\hline
\end{tabular}

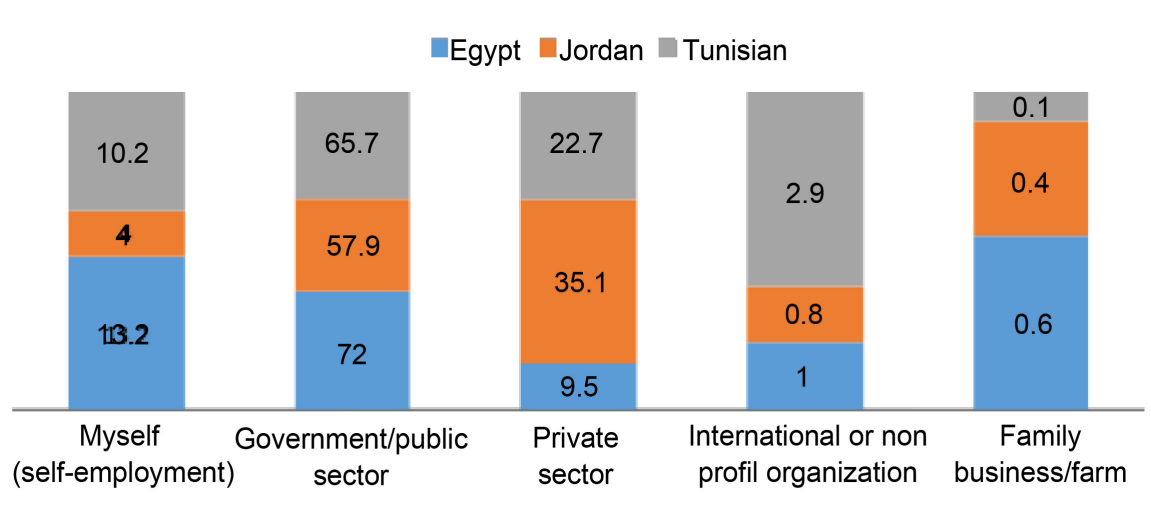

Figure 2. Desired future sector of employment of current students (\%). Data Source: ILO. Graphics: constructed by author.

respectively. This survey aimed at collecting more exhaustive information about youth labor market situation and providing element of responses on the obstacles and difficulties encountered by young people in the labor market transition process.

Our analysis underscored the main characteristics of Egypt, Jordan and Tunisian labor market and the youth employment situation in the context of demographic transition and economics globalization.

To explain the spread of the distribution of earnings, especially for college graduates, we need to highlight the role of skill mismatches and more particularly the overeducation phenomena in wage-setting process. In fact, as indicated previously and especially for Tunisia, workers in overeducation situation shall be subject to a wage penalty and may see cuts in their real wage. Based on the survey results (Figure 3), it can be concluded that among the three countries, Tunisia is particularly affected by overeducation phenomena with more than 25 percent against 12 percent and 10 percent for Egypt and Jordan respectively.

As indicated by Figure 4 overdecuation affects particularly Tunisian university graduates with $31 \%$ against $0 \%$ for primary and $20 \%, 25 \%$ and $28.5 \%$ for 


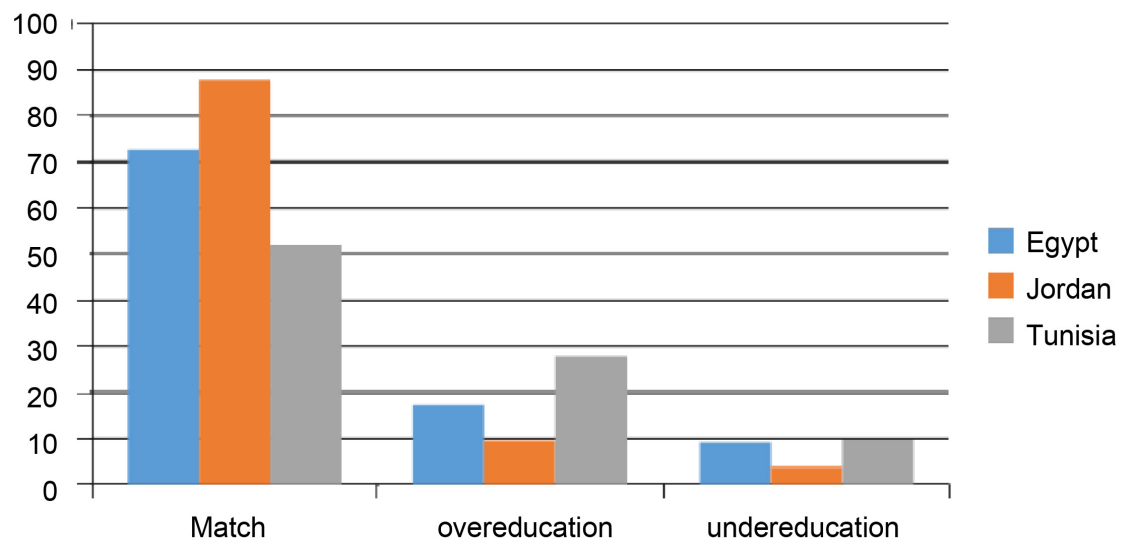

Figure 3. Global incidence of job mismatches in \%. Data Source: ILO. Graphics: constructed by author.

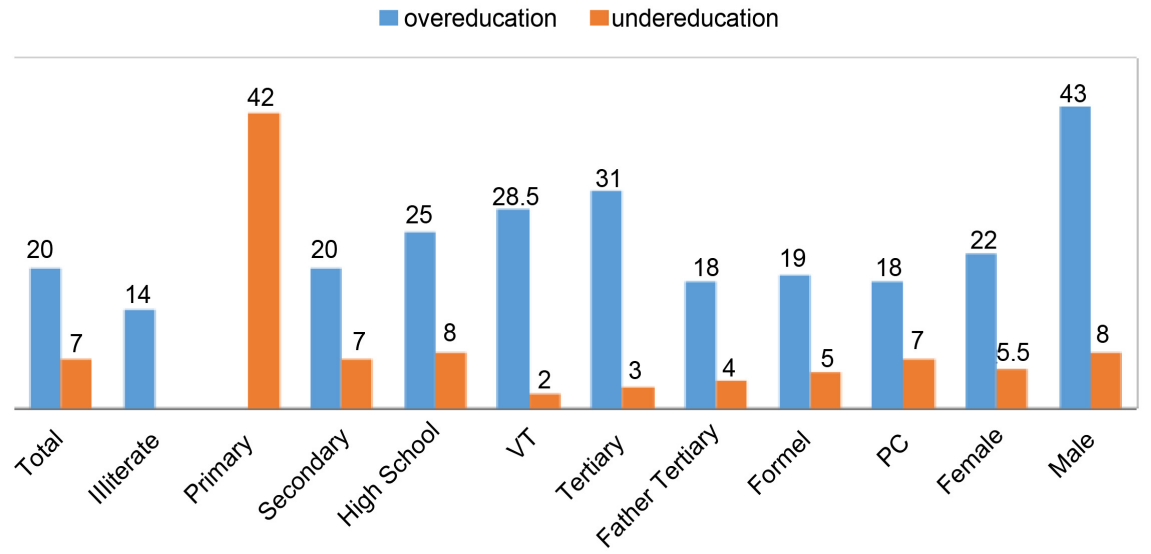

Figure 4. Incidence of job mismatches in Tunisia in \%. Data Source: ILO. Graphics: constructed by author.

secondary, high school and vocational training respectively. For Egypt, technical secondary (20 per cent) and to a lesser degree university.

It should be stressed that the overeducation phenomenon has a much broader scope and far more serious consequences than we imagine since this category of workers are subject to a wage penalty. We tried, by means of a wide range of estimations models to quantify the contribution of each skill mismatch in the wages variations and evaluate its impact on return at education.

2) Econometric estimation.

In this section, we develop the empirical evidence on the role played by skill mismatches in wage setting process conditional to the level education. We use the theoretical frameworks propose par Throw (1975) and Duncan and Hoffman (1981) to build our wage equations:

$$
\ln \left(w_{i}\right)=\beta_{0}+\beta_{1} L E_{i}+\beta_{2} L E_{i} \times \text { over }_{i}+\beta_{3} L E_{i} \times \text { under }_{i}+X_{i}^{\prime} \beta+\varepsilon_{i}
$$

Through this specification, we assume that, for any educational level, all years of schooling affect equally the individual's wage. We also assume that, for any educational level, all years of schooling affect equally the individual's wage. The 
specification (1) indicates that the wages $(\mathrm{w})$ received by surveyed are explained by education which can be defined by qualitative variable (lev) including seven level of education (primary, lower secondary, upper secondary, post-secondary non-tertiary, Bachelor, Master, Doctorat or equivalent). In order to evaluate the return at education according to its match with the job being performed, we propose an alternative specification to Duncan and Hoffman one by considering two cross dummies variables and express the return to an additional year of overeducation and undereducation respectively. Overeducation and undereducation are quantified from the responses to the following question: Do you feel your education/training qualifications are relevant in performing your present job? The respondent is sorted into the match, overeducation and undereducation category if his answer is "yes", "'no, I feel overqualified", "no, I experience gaps in my knowledge and skills/ need additional training" respectively.

The estimations results reported in Table 1, indicate that the return on additional year of education in Tunisia was about $8 \%$ while in Egypt and Jordan an additional year of schooling increases wages by $4.6 \%$ and $4.7 \%$ respectively. Morocco has a low return at education which does not exceed 3\%. It is important to note that for Tunisia men return at education was more than 25 percentages higher than the women, indicating the presence of strong gender discrimination. This wage discrimination between men and women is marginal in Egypt andJordan. The negative and statistically significant value of cross variable coefficient (2\%) reflects the wage penalty for Tunisian overeducated workers compared to appropriately allocated workers; that is the negative difference reflects the loss of individuals who has an extra year of overeducation compared with individuals who, with the same level of education is classified in match category. The coefficient associated to the cross a variable LE X under is not statistically significant, indicating that the youth labor market in Tunisia is not affected by undereducation problem. For Egypt and Jordan these cross effects are marginal and not significant suggesting that the youth labour market frictions in the both countries are less strongly than in Tunisia.

An alternative way to quantify education is to consider a discrete variables given by a set of dummy variables that represent the highest education level attained by surveyed. In the latter case, the wage equation would then be specified as follows:

$$
\begin{aligned}
\ln \left(w_{i}\right)= & \alpha+\alpha_{1} \text { pri }_{i}+\alpha_{2} \text { secon }_{i}+\alpha_{3} \text { ter }_{i}+\alpha_{4} \text { ter }_{i} \times \text { over } \\
& +\alpha_{4} \text { pri }_{i} \times \text { under }+X_{i}^{\prime} \beta+\varepsilon_{i}
\end{aligned}
$$

where pri, secon and ter are dummies variable that take one if the individual has complete the primary stage, secondary stage and tertiary stage respectively.

To contain the dummy variables trap (Table 4), we omit from the regression lower secondary, which will be considered as a reference modality. To stress on the previous specification and to highlight the impact of skill mismatch on return at education, we considered interaction variables for the levels of education. Contrary to the specification (1), undereducation was crossed with primary 
dummy variable (pri); the argument put forward is based on our previous descriptive analysis for which the overeducation affects more significantly the secondary (for Egypt) and university (for Tunisia) graduates while the undereducation problem is more present among surveyed who attained primary level.

By contrast with the first specification (Table 5), the latter one has the advantage of allowing one to estimate the return at education associated with a specific educational level, which can be calculated as follows:

$$
R_{i}=\frac{\alpha_{i}-\alpha_{j}}{S_{i}-S_{j}}, i>j
$$

where the return is associated with an educational level relative to the preceding educational level and is the coefficients associated with those levels in the regression (2); and are the number of year's schooling covered by levels and respectively. According to this return to education definition and based on estimation results reported in Table 4, one observes that the marginal benefits the individual expects to obtain from secondary level to tertiary level is about $6.70 \%, 12 \%$ and $5.87 \%$ in Egypt, Jordan and Tunisia. In terms of, these empirical findings that it is more interesting for Egypt and Jordan youth to enter the work force

Table 4. Return at education estimations.

\begin{tabular}{|c|c|c|c|c|c|c|c|}
\hline Colonne1 & Colonne2 & Colonne3 & Colonne4 & Colonne5 & Colonne6 & Colonne7 & Colonne8 \\
\hline & & EGYPT & & JORDAN & & TUNISIA & \\
\hline Genre & & -0.069 & -0.069 & -0.047 & -0.048 & $0.267^{\star *}$ & $0.279^{* *}$ \\
\hline Age & & $0.488^{\star * *}$ & $0.488^{\star * *}$ & $0.368^{\star * *}$ & $0.366^{\star * *}$ & $0.386^{* *}$ & $0.38^{\star *}$ \\
\hline Age2 & & $-0.010^{* * *}$ & $-0.010^{\star * *}$ & $-0.005^{\star * *}$ & $-0.0059^{* * *}$ & $-0.0072^{\star *}$ & $-0.007^{\star *}$ \\
\hline L.E & & $0.046^{\star}$ & $0.047^{\star}$ & $0.066^{\star *}$ & $0.069^{* *}$ & $0.078^{\star * *}$ & $0.0934^{\star * *}$ \\
\hline L.E X under & & & -0.022 & & 0.0805 & & -0.0004 \\
\hline L.E X over & & & -0.008 & & -0.024 & & $-0.0287^{\star * *}$ \\
\hline $\mathrm{R} 2$ & & 0.905 & 0.905 & 0.908 & 0.907 & 0.902 & 0.905 \\
\hline
\end{tabular}

Table 5. Return at education estimation (following the level education).

\begin{tabular}{ccccccc}
\hline Colonne1 & EGYPT & Colonne2 & JORDAN & Colonne3 & TUNISIA & Colonne4 \\
\hline PRI & 0.027 & 0.027 & -0.51 & -0.51 & $-0.221^{*}$ & -0.204 \\
SECO & $0.433^{*}$ & $0.611^{*}$ & 0.21 & 0.21 & 0.09 & 0.091 \\
TER & $0.340^{* *}$ & $0.271^{*}$ & 0.292 & 0.31 & $0.325^{* * *}$ & $0.442^{* * *}$ \\
Genre & -0.151 & -0.144 & 0.0041 & -0.0074 & 0.271 & $0.274^{* * *}$ \\
Age & $0.493^{* * *}$ & $0.491^{* * *}$ & 0.391 & $0.391^{* * *}$ & $0.431^{* *}$ & $0.436^{* * *}$ \\
Age 2 & $-0.010^{* * *}$ & $-0.010^{* * *}$ & -0.006 & $-0.006^{* * *}$ & $-0.083^{* *}$ & $-0.0084^{* * *}$ \\
SECOND X & & -0.366 & & -0.308 & & $-0.366^{* *}$ \\
OVER & & 0.176 & & -0.165 & & -0.039 \\
UNIV X OVER & & 0.906 & 0.955 & 0.988 & 0.935 & 0.936 \\
R2 & 0.902 & 0.353 & 0.701 & 0.721 & 0.467 & 0.461 \\
SE & 0.354 & & & & & \\
\hline
\end{tabular}


directly after graduating from high school instead of pursuing higher education since university return at education is about $-2.25 \%$ and $2 \%$ respectively for the two countries.

This finding is supported by the high return to education increase (12\%) when Jordan individuals have completed the upper secondary stage. However, the difference between secondary stage and primary stage return at education does not exceed $6.7 \%$ and $5.18 \%$ for Egypt and Tunisia respectively. Table 5 reports the return at education at different levels of education. It is important to note that the difference between upper secondary stage and lower secondary stage return at education is about $43 \%, 21 \%$ and only 9.\%; for Egypt, Jordan and Tunisia respectively, indicating that the investment in upper secondary education is greatly profitable for Egyptian's individuals and to lesser extent for Jordanians ones. It is important to note that, for Tunisia, the difference between upper secondary stage and lower secondary stage return at education is about $9.5 \%$; while the return to university level is $35 \%$ higher than the reference one (lower secondary) indicating that the investment in higher education is greatly profitable. However, this gain was only acquired by individuals with skills through the education process match those required by the market. In fact, at university level, the wage penalty is significantly high, approaching $36 \%$; that is the wage penalty for overeducated compared to appropriately allocated workers increased by $36 \%$.

\section{Causality Inference with Matching Technique}

The most recent methodological developments in this area have called into question the estimates obtained by the econometric models since there is a difference between over-educated employees and those who have been employed in a job compatible with their educational qualifications (the well-matched). In this case, the estimated causal effect may be due to the assumption of the model in which the over-educated sample is not randomly assigned.

Following the invalidity of traditional approaches to solving such a problem that will certainly influence in a negative way the robustness of the estimated effect of over-education, instead of being a result obtained from the observations of data, it will be a result deduced from the hypotheses of an econometric model.

Our goal is to determine the causal effect of over-education on salary level through matching techniques that will serve us to improve causal inference.

We will not be interested in the effect of undereducation for many reasons: first, its effect is already known and it is useless to study it. Secondly, there are not enough observations for under-educated individuals, and thirdly, the wage penalty for this group of persons is not as serious as in the case of overeducation.

We note from the available data that the phenomenon of over-education is quite present and especially among those who have reached secondary and tertiary education. We will then pay particular attention to the estimation of the causal effect for these two levels of education and especially the tertiary level since new graduates are the most concerned. 
The question is how to distinguish between the case where the effect of over-education on wages comes essentially from over-education itself and the case where this causal effect is due to the assumptions of a statistical model. To overcome such a difficulty and also the problem of difference between over-educated workers and those who are initially well matched, we use the Matching method as a non-parametric technique of causal inference. The principle of this method is to find units among the control group (the well-matched) that are similar to the units treated (the over-educated) in terms of observable characteristics such as (age, sex, type of work contract, etc.) so-called covariates. After selecting and matching similar neighbors with their processed units, we can now determine the causal effect while comparing the potential results in the matched sample. The peculiarity of this method is that the treatment effect to be sought is based on the observations and not on the functional form of a statistical model. The major limitation of Matching is that it cannot control the unobservable variables that can affect the treatment variable (over-education) as well as wages.

To solve this problem, units are selected according to the same level of education. Overeducation is well observed and it is frequently present especially for the following two levels of education: secondary and tertiary; thus, we tend to highlight, by means of Matching method the negative effect of overeducationon earnings (wage penalty).

It should be noted that for the dichotomous and categorical variables, the Matching is perfect whereas for the continuous variables it is not the case; that's why it is not recommended to apply an exact matching on continuous characteristics like the age for example. To contain this problem, we adopt the caliper matching which consists on fixing an upper bound for which individuals should not exceeded to be considered as close neighbors.

The following three consecutive tables report the estimations results of the average treatment effect on treated noted ATT for Tunisia, Egypt and Jordan respectively.

One can observe from Table 6 that the estimation results based on matching technique confirm our previous empirical findings, which reveal the significant and negative relationship between over-education and wages. In fact, By means of these two econometrics foundations, we highlight and reinforce the theories of the wage penalty, due to "educational mismatch. It is important to note that this phenomenon concerns more specifically Tunisia youth labor market. More particularly and as indicated by our empirical results for the three countries, the wage penalty increases from one level of education to a higher one with $7 \%$, 9.2\% and $12.5 \%$ for primary, secondary and tertiary levels respectively ${ }^{2}$.

The treatment effect analysis using the ILO survey data from Tunisia, Egypt and Jordan reveals that the overeducated workers with tertiary education level suffer about $14 \%$ loss in earnings in comparison with the well-matched in Tunisia while, In Egypt and Jordan wage penalty register respectively 15\% and $12.6 \%$.

\footnotetext{
${ }^{2}$ For Egyptian case.
} 
Table 6. Return at education estimation (Matching method).

\begin{tabular}{cc}
\hline TUNISIA: & Estimated ATT \\
\hline Primary & $-17.78 \%^{* *}$ \\
Secondary & $-11.80 \%$ \\
Tertiary & $-11.90 \%$ \\
\hline EGYPT: & $-14.11 \%^{*}$ \\
\hline Exact Matching on all levels of education & Estimated ATT \\
Primary & $-15.00 \%^{* *}$ \\
Secondary & $-7.00 \%$ \\
Tertiary & $-9.26 \%$ \\
\hline JORDAN: & $-12.5 \%^{*}$ \\
\hline Tertiary & Estimated ATT \\
\hline Primary & $-12.6 \%{ }^{* *}$ \\
\hline Exact Matching on all levels of education & $-10.62 \%$ \\
\hline
\end{tabular}

As described by Sicherman (1991), "Workers who are working in occupations that demand less schooling than they actually have (overeducated) get higher wages than their coworkers (holding other characteristics constant) but lower wages than workers with similar levels of schooling who work in jobs in which their schooling equals what is required."

\section{Conclusion}

This research paper presents an empirical investigation of the impact of labour market frictions on return to education. We are particularly interested as to the identification of educational mismatch determinants and to the evaluation of the over-education consequences on the return at education. Few studies, however, have examined the effects of educational mismatch on return to higher education and have quantified the wage penalties induced by the over-education effects, particularly in Tunisia.

In this study, we attempted to enrich this line of research on the basis of two theoretical perspectives: Firstly, we studied, by means of estimating extended Mincerian wage equation, the private return to education in Egypt, Jordan and Tunisia. Secondly, we considered the existence of educational mismatches in order to identify their determinants. Finally, we used matching method in order to perform our methodology and evaluate the robustness of our estimations results.

Our empirical findings show the presence of a wage penalty for over-education, 
especially among university graduates, which is deemed to be at a cost for individuals, as over-educated workers may earn less than more well-matched employees. This type of mismatch is largely due to inefficiency in the allocation of educational resources in Tunisia. Beside wage penalties, over-education could also result in significant costs for society as a whole, as well as for firms and individuals. It implies a loss in efficiency for firms if the productivity of overeducated workers is systematically regarded as lower than those who are considered to be well matched.

In summary, one important impact of over-education is that well matched workers are perceived to have more abilities than overeducated workers. A potential solution to avoid this type of mismatch is to contain the overcrowding in higher education and put more efforts into skill training, especially in upper secondary schools.

\section{Conflicts of Interest}

The authors declare no conflicts of interest regarding the publication of this paper.

\section{References}

Angrist, J. D., \& Krueger, A. B. (1991). Does Compulsory School Attendance Affect Schooling and Earnings? The Quarterly Journal of Economics, 106, 979-1014. https://doi.org/10.2307/2937954

Assaad, R. (1997). The Effects of Public Sector Hiring and Compensation Policies on the Egyptian Labor Market. The World Bank Economic Review, 11, 85-118. https://doi.org/10.1093/wber/11.1.85

Becker, G. (1964). Human Capital: A Theoretical and Empirical Analysis, with Special Reference to Education. New York: National Bureau of Economic Research.

Becker, G., \& Chiswick, R. (1966). Education and the Distribution of Earnings. The American Economic Review, 56, 358-369.

Bender, K. A., \& Roche, K. (2013). Educational Mismatch and Self-Employment. Economics of Education Review, 34, 85-95. https://doi.org/10.1016/j.econedurev.2013.01.010

Budría, S., \& Moro-Egido, A. I. (2008). Education, Educational Mismatch, and Wage Inequality: Evidence for Spain. Economics of Education Review, 27, 332-341. https://doi.org/10.1016/j.econedurev.2006.10.005

Cainarca, G. C., \& Sgobbi, F. (2012). The Return to Education and Skills in Italy. International Journal of Manpower, 33, 187-205. https://doi.org/10.1108/01437721211225444

Card, D. (1999). The Causal Effect of Education on Earnings. In O. Ashenfelter, \& D. Card (Eds.), Handbook of Labor Economics (Vol. 3A, pp. 1801-1863). Amsterdam: North Holland. https://doi.org/10.1016/S1573-4463(99)03011-4

Daly, M. C., Büchel, F., \& Duncan, G. J. (2000). Premium and Penalties for Surplus and Deficit Education: Evidence from United States and Germany. Economics of Education Review, 19, 169-178. https://doi.org/10.1016/S0272-7757(99)00041-2

David, A., \& Nordman, C. (2017). Education Mismatch and Return Migration in Egypt and Tunisia. In F. Marie-Laurence, T. Eggerickx, \& B. Schoumaker (Eds.), Les 
migrations de retour en Afrique, Espace, Populations, Société, No. 1, Article No. 7110. https://doi.org/10.4000/eps.7110

Dolton, P., \& Siles, M. (2003). The Determinants and Consequences of Overeducation. In Buchel, de Grip, \& Mertens (Eds.), Overeducation in Europe (pp. 189-217). Cheltenham: Edward Elgar.

Duncan, G., \& Hoffman, S. D. (1981). The Incidence and Wage Effects of Overeducation. Economics of Education Review, 1, 75-86. https://doi.org/10.1016/0272-7757(81)90028-5

Flisi, S., Goglio, V. et al. (2017). Measuring Occupational Mismatch: Overeducation and Overskill in Europe-Evidence from PIAAC. Social Indicators Research, 131, 1211-1249. https://doi.org/10.1007/s11205-016-1292-7

Freeman, R. B. (1976). The Overeducated American. New York: Academic Press.

García-Pozo, A., Sánchez-Ollero, J. L., \& Marchante-Mera, A. (2014). Educational mismatch and Returns on Human Capital in the Spanish Hospitality and Travel Agency Sectors. Tourism Economics, 20, 337-353. https://doi.org/10.5367/te.2013.0273

Hartog, J. (2000). Over-Education and Earnings: Where Are We, Where Should We Go? Economics of Education Review, 19, 131-147. https://doi.org/10.1016/S0272-7757(99)00050-3

Kalfa, E., \& Piracha, M. (2017). Immigrants' Educational Mismatch and the Penalty of Overeducation. Education Economics, 25, 462-481. https://doi.org/10.1080/09645292.2017.1298728

Mateos Romero, L., Murillo Huertas, I. P., \& Salinas Jiménez, M. M. (2017). Wage Effects of Cognitive Skills and Educational Mismatch in Europe. Journal of Policy Modeling, 39, 909-927. https://doi.org/10.1016/j.jpolmod.2017.08.001

Mincer, J. (1974). Schooling, Experience and Earnings. New York: Columbia University Press.

Murillo, I. P., Rahona-López, M., \& Salinas-Jiménez, M. M. (2012). Effects of Educational Mismatchon Private Returns to Education: An Analysis of the Spanish Case (1995-2006). Journal of Policy Modeling, 34, 646-659.

https://doi.org/10.1016/j.jpolmod.2011.07.012

Pecoraro, M. (2016). The Incidence and Wage Effects of Overeducation Using Vertical and Horizontal Mismatch in Skills: Evidence from Switzerland. International Journal of Manpower, 37, No. 3.

Quintano, C., Castellano, R., \& D’Agostino, A. (2008). Graduates in Economics and Educational Mismatch: The Case Study of the University of Naples "Parthenope". Journal of Education and Work, 21, 249-271. https://doi.org/10.1080/13639080802214118

Rumberger, R. W. (1981). The Rising Incidence of Overeducation in the US Labour Market. Economics of Education Review, 1, 293-314. https://doi.org/10.1016/0272-7757(81)90001-7

Salehi-Isfahani, D., Tunali, I., \& Assaad, R. (2009). A Comparative Study of Returns to Education of Urban Men in Egypt, Iran, and Turkey. Middle East Development Journal, 1, 145-187. https://doi.org/10.1142/S1793812009000085

Sharma, S., \& Sharma, P. (2017). Educational Mismatch and Its Impact on Earnings: Evidence from Indian Labour Market. International Journal of Social Economics, 44, 1778-1795. https://doi.org/10.1108/IJSE-05-2016-0134

Sicherman, N. (1991). “Overeducation” in the Labour Market. Journal of Labor Economics, 9, 101-122. https://doi.org/10.1086/298261 
Sicherman, N., \& Galor, O. (1990). A Theory of Career Mobility. Journal of Political Economy, 98, 169-192. https://doi.org/10.1086/261674

Sloane, P., Battu, H., \& Seaman, P. (1999). Overeducation, Undereducation and the British Labour Market. Applied Economics, 31, 1437-1453. https://doi.org/10.1080/000368499323319

Tarvid, A. (2015). The Effectiveness of Access Restriction to Higher Education in Decreasing Overeducation. Economic Analysis and Policy, 45, 11-26. https://doi.org/10.1016/j.eap.2014.12.003

Thurow, L. C. (1975). Generating Inequity. New York: Basic Books.

Tsai, Y. (2010). Returns to Overeducation: A longitudinal Analysis of the U.S. Labor Market. Economics of Education Review, 29, 606-617.

Vahey, S. (2000). The Great Canadian Training Robbery: Evidence on the Returns to Educational Mismatch. Economics of Education Review, 19, 219-227. https://doi.org/10.1016/S0272-7757(98)00029-6

Van de Werfhorst, H. G., \& Mijs, J. J. B. (2010). Achievement Inequality and the Institutional Structure of Educational Systems: A Comparative Perspective. Annual Review of Sociology, 36, 407-428. https://doi.org/10.1146/annurev.soc.012809.102538

Verdugo, R. R., \& Verdugo, N. T. (1989). The Impact of Surplus Schooling on Earnings: Some Additional Findings. Journal of Human Resources, 24, 629-643. https://doi.org/10.2307/145998

Zamfir, A. M., Matei, M. M., \& Lungu, E, O. (2013). Influence of Education-Job Mismatch on Wages among Higher Education Graduates. Procidia-Social and Behavioral Sciences, 89, 2293-2297. https://doi.org/10.1016/j.sbspro.2013.08.849 